УДК 004.4:617.75

I. С. Мінтій,

кандидат педагогічних наук, доцент

(Криворізький державний педагогічний університет)

irina.mintiyakdpu.edu.ua

ORCID: 0000-0003-3586-4311

Т. А. Вакалюк,

кандидат педагогічних наук, доцент

(Житомирський державний університет імені Івана Франка)

neotalzu.edu.ua

ORCID: 0000-0001-6825-4697

В. М. Пірогов,

студент

(Криворізький державний педагогічний університет)

pirogov1818@gmail.com

ORCID: 0000-0002-8822-2649

А. М. Горло,

студентка

(Криворізький державний педагогічний університет) stifa1996@gmail.com

ORCID: 0000-0002-2954-8200

М. М. Мінтій,

учитель фізики, інформатики

(Криворізька СШ № 9)

mikhail.mintii9@gmail.com

ORCID : 0000-0002-0488-5569

\title{
АНАЛІЗ ПРОГРАМНИХ ЗАСОБІВ ДЛЯ ЛЮДЕЙ ІЗ ПОРУШЕННЯМИ ЗОРУ
}

Розглянуто програмні засоби (ПЗ) для людей із частковою чи повною сліпотою (перший напрям) та колірною сліпотою (другий напрям). Проведено порівняльний аналіз за наступними критеріями: ПЗ першого напряму - основні функиії, додаткові можливості, розповсюдження та компанія-розробник; ПЗ другого напряму - тип, функиї, розповсюдження та компанія-розробник. Проілюстровано приклади роботи ичих ПЗ. Особливу увагу акцентовано на веб-додатку для конвертації колірних стилів сайту для людей з порушенням кольоросприйняття.

Ключові слова: порушення зору, повна сліпота, часткова сліпота, колірна сліпота, порушення кольоросприйняття, адаптаиія дизайну сайту.

Постановка проблеми. Одним із пріоритетних завдань сьогодення є інклюзія - розширення участі всіх громадян у житті суспільства, і в першу чергу - людей, які мають певні труднощі у фізичному чи розумовому розвитку. У всьому світі близько 253 мільйонів людей страждають від певних порушень зору [1]. У час тотальної комп'ютеризації такі вади можуть значно обмежувати доступ до цифрових ресурсів.

Аналіз наукових праць. Різні аспекти порушень зору досліджуються у роботах Ю. Александрова, Е. Васильєвої, М. Гарена, А. Горло, Р. Коллінж, О. Курмишевої, Д. Паскала, Ч. Педхема, Дж. Сондерс, М. Фершильда, Е. Шредінгера та ін.

Метою даної статті $є$ аналіз ПЗ для людей з порушеннями зору. У цій проблемі слід виокремити два напрями - власне повна чи часткова сліпота та колірна сліпота. Адже дальтонізм (колірна сліпота) зустрічається у близько 5-8 \% чоловіків і 0,5 \% жінок [2: 63].

Виклад основного матеріалу. Для початку дослідимо ПЗ першого напряму (повна чи часткова сліпота), серед них слід розглянуи (https://www.freedomscientific.com/JAWSHQ/JAWSHeadquarters01), NVDA (http://sds.ktu10.com/node/71), Magnus (https://www.clarosoftware.com/search?q=Magnus) та Екранна лупа (https://support.microsoft.com/ruru/help/11542/windows-use-magnifier). Порівняльний аналіз цих ПЗ виконано у табл. 1. Приклади роботи наведено на рис. 1 - рис. 3 .

Таблиия 1.

Програмні засоби для людей з повною чи частковою сліпотою

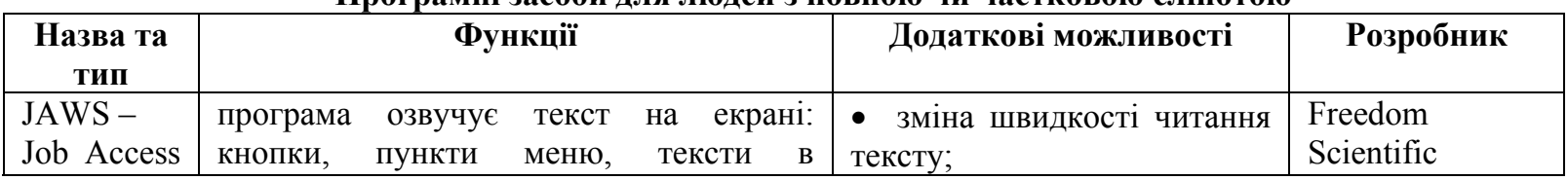

(C) Мінтій І. С., Вакалюк Т. А., Пірогов В. М., Горло А. М., Мінтій М. М., 2018 


\begin{tabular}{|c|c|c|c|}
\hline $\begin{array}{c}\text { Назва та } \\
\text { тиII }\end{array}$ & Функції & Додаткові можливості & Розробник \\
\hline 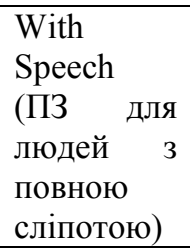 & $\begin{array}{l}\text { документах, тощо та натиснення клавіш } \\
\text { клавіатури; } \\
\text { взаємодія } 3 \text { електронними пристроями } \\
\text { введення/виведення для сліпих: дисплей } \\
\text { та дошка Брайля }\end{array}$ & $\begin{array}{l}\text { - } \quad \text { паузи між словами; } \\
\text { - } \quad \text { вибір мови; } \\
\text { • } \quad \text { налаштування режимів } \\
\text { читання }\end{array}$ & \\
\hline $\begin{array}{l}\text { NVDA - } \\
\text { Non Visual } \\
\text { Desktop } \\
\text { Access } \\
\text { (П3 для } \\
\text { людей } 3 \\
\text { частковою } \\
\text { сліпотою) } \\
\end{array}$ & 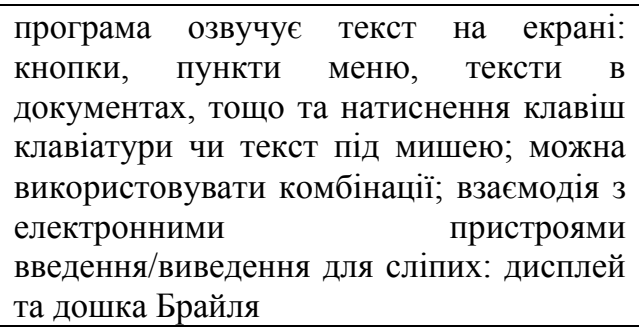 & $\begin{array}{l}\text { - } \quad \text { вибір мови (у списку }-44 \\
\text { мови); } \\
\text { - } \quad \text { зміна швидкості читання } \\
\text { тексту; } \\
\text { - паузи між словами; } \\
\text { - } \quad \text { налаштування початку } \\
\text { роботи програми }\end{array}$ & $\begin{array}{l}\text { NVDA (ліцензія } \\
\text { GNU General } \\
\text { Public License } \\
\text { (версія 2) }\end{array}$ \\
\hline $\begin{array}{l}\text { Екранна } \\
\text { лупа (П3 } \\
\text { для людей } \\
3 \\
\text { частковою } \\
\text { сліпотою) } \\
\end{array}$ & $\begin{array}{l}\text { збільшує зображення монітора від } 2 \text { до } \\
16 \text { разів }\end{array}$ & $\begin{array}{llll}\begin{array}{l}\text { запуск } \\
\text { екран }\end{array} & \text { програми на весь } \\
\end{array}$ & $\begin{array}{l}\text { Microsoft } \\
\text { (встановлено за } \\
\text { замовчуванням } \\
\text { в усіх OC } \\
\text { Windows (3 MS } \\
\text { Windows 7) } \\
\end{array}$ \\
\hline $\begin{array}{l}\text { Magnus } \\
\text { (П3 для } \\
\text { людей } 3 \\
\text { частковою } \\
\text { сліпотою) }\end{array}$ & $\begin{array}{l}\text { збільшує зображення в околі від } 2 \text { до } 16 \\
\text { разів }\end{array}$ & - & Claro Software \\
\hline
\end{tabular}

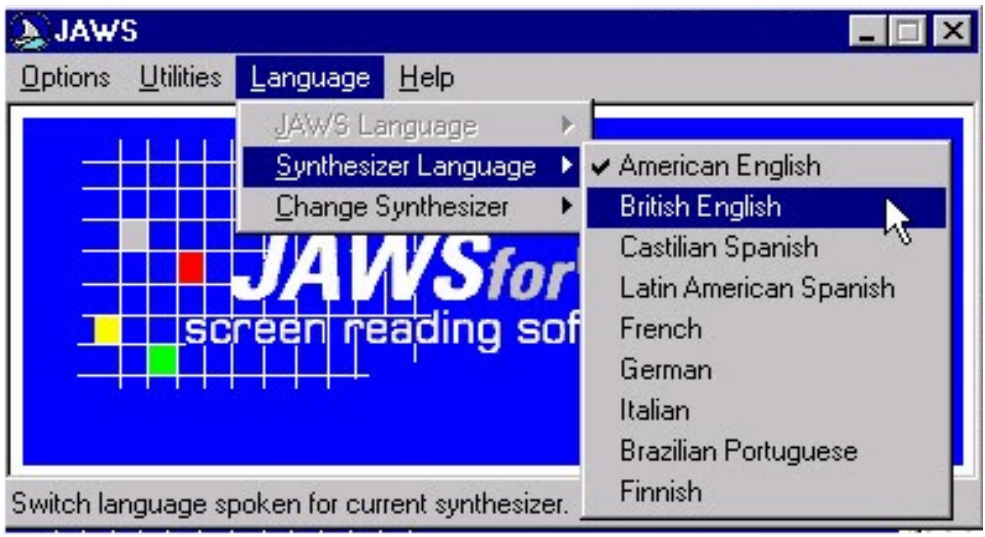

Рис. 1. Інтерфейс програми JAWS

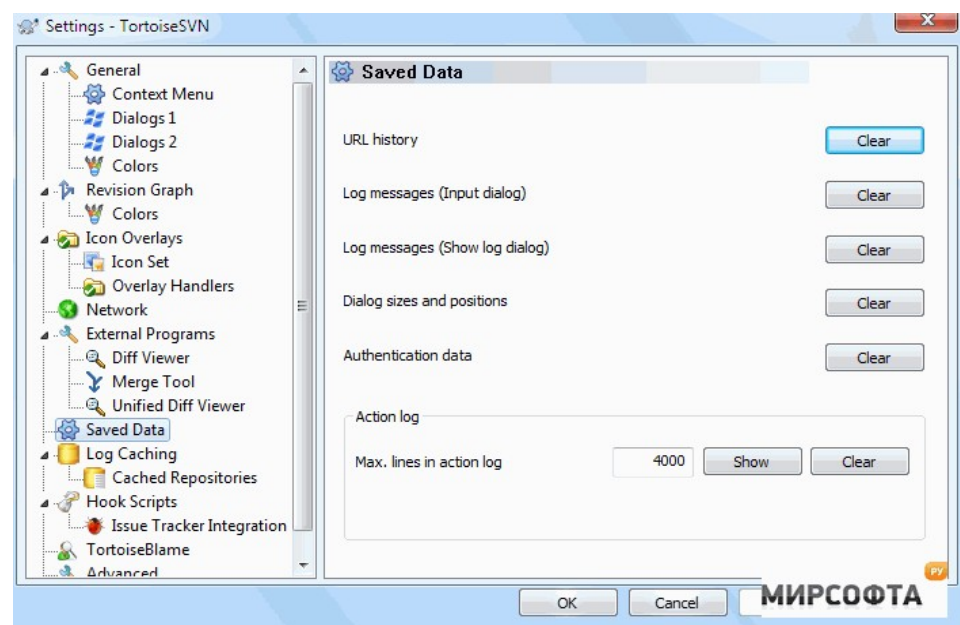

Рис. 2. Інтерфейс програми NVDA 


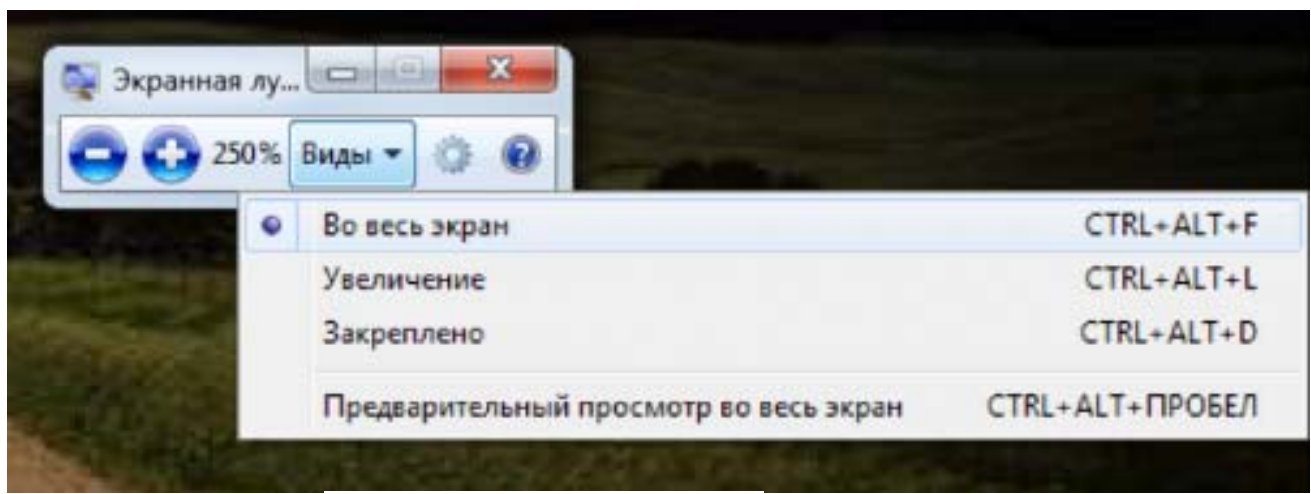

Рис. 3. Інтерфейс програми Екранна лупа

Перед аналізом ПЗ для людей, які мають колірну сліпоту, розглянемо деякі теоретичні відомості 3 проблем кольоросприйняття.

Кількість кольорів та їх відтінків, які може сприймати людина дуже велика. Колір має не тільки фізичну дію на людину, а й психологічну. Залежно від різних кольорів може змінюватися психологічний стан людини, її працездатність та активність. Кольоровий зір дуже важливий для орієнтації людини у навколишньому середовищі та дає змогу краще сприймати світ.

Сприйняття кольору залежить від фізичних властивостей світла та від його інтерпретації зоровою системою людини. Здатність розрізняти кольори залежить від довжини електромагнітної хвилі, тобто світла. Промінь світла при відображенні заломлюється та розкладається на хвилі різної довжини, які сприймаються нашим оком як спектральні кольори.

Хоча й головним фізичним параметром кольору $\epsilon$ кольоровий тон, але сприйняття кольору визначається трьома атрибутами світла: довжиною хвилі, інтенсивністю та спектральною чистотою. Кожному із цих параметрів відповідають особливі психологічні аспекти відчуття кольору: кольоровий тон, яскравість та насиченість [3: 195].

Зв’язок між фізичними та психологічними параметрами кольору

Табличя 2.

\begin{tabular}{|l|l|}
\hline \multicolumn{1}{|c|}{ Фізичний параметр } & \multicolumn{1}{|c|}{ Психологічний параметр } \\
\hline Довжина хвилі & Кольоровий тон \\
\hline Інтенсивість & Яскравість \\
\hline Спектральна чистота & Насиченість \\
\hline
\end{tabular}

Довжина хвилі - промінь світла, що заломлюється на хвилі різної довжини. Око людини, сприймаючи хвилі з різних діапазонів довжини розрізняє спектральні кольори, які знаходяться у видимій зоні від 380 до 760 нм.

Інтенсивність - це швидкість з якою пучок світла рухається за одиницю часу.

Спектральна чистота - це кількісне визначення монохроматичності даного світла [4: 30]. Спектральні кольори мають максимальну чистоту кольору, яка дорівнює одиниці. У спектральних кольорах потужність білого світла дорівнює нулю [5: 35].

Кольоровий тон - це якість кольору, яка визначається довжиною хвилі (у нм) та дорівнює одному із спектральних кольорів або не спектральних (пурпурних кольорів) [6: 33].

Яскравість (світлота) - кількісна характеристика світла. 3 іiі допомогою можна порівнювати інтенсивність випромінювання різних джерел між собою. Яскравість пропорційна сумі інтенсивностей усіх складових кольорового спектру світла [5: 34].

Насиченість - ступінь відмінності хроматичного кольору від рівного йому по яскравості (світлоті) ахроматичного кольору [6:33].

Кольоровий зір людини залежить від здатності ока сприймати кольори та їх відтінки. Око людини здатне сприймати до 13000 кольорів та їх відтінків. Хоча механізм перетворення фізичних характеристик світла у психофізичні до кінця не вивчений, існує безліч теорій, які намагалися пояснити механізми кольорового зору людини. Основна теорія пояснення кольорового зору людини - це трьохкомпонентна теорія кольорового зору (теорія Юнга-Гемгольца). Оскільки наше око містить три види колбочок, які сприймають три кольори. Цих трьох кольорів достатньо для змішування та формування усіх інших кольорів спектру. Колбочки сітківки ока сприймають хвилі різної довжини, тобто утворюють три групи iз різною спектральною чутливістю [7: 31].

Різна спектральна чутливість колбочок залежить від довжини хвилі світла і, відповідно, кожна група колбочок має назву, згідно довжини хвилі, яку вона сприймає. Отже є S (small), M (middle), L (long) колбочки, тобто "сині" колбочки (короткий діапазон), "зелені" колбочки (середній діапазон), "червоні" колбочки (довгий діапазон) (рис. 4). Завдяки наявності усіх груп колбочок, людина здатна змішувати та 
отримувати всі кольори, які доступні людському оку. Проте не у всіх $є$ всі три види колбочок у наявності, тому такі люди мають певні порушення кольоросприйняття.

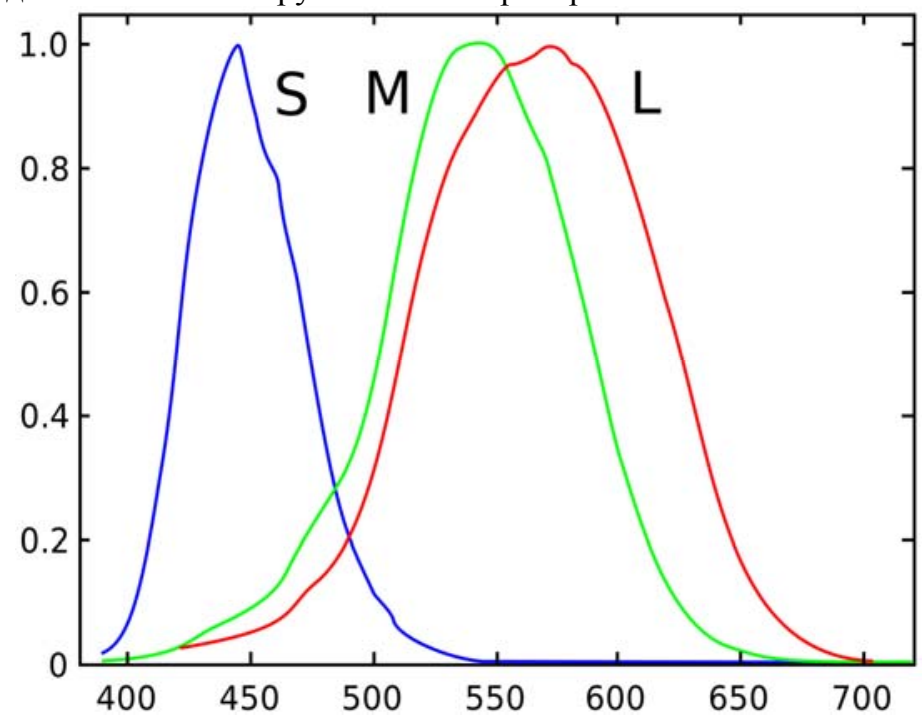

Рис. 4. Спектри поглинання одиночних колб ока людини за даними мікроспектрофотометрії

Порушення сприйняття кольорів вперше було згадано Д. Дальтоном. Тому часткову або повну колірну сліпоту назвали терміном дальтонізм.

У людей, хворих на дальтонізм, відсутня одна із трьох колбочкових кольоросприймаючих речовин. Дальтонізм пов'язують із відсутністю певних генів у хромосомі, яка визначає стать [2: 63].

Аномалії кольорового зору систематизовано у табл. 3 .

Таблиця 3.

Аномалії кольорового зору

\begin{tabular}{|l|l|l|}
\hline \multicolumn{2}{|c|}{ Класифікація } & \multicolumn{2}{c|}{ Розповсюдженість, \% } \\
\cline { 2 - 3 } чоловіки & жінки \\
\hline Аномальний трихроматизм & \multicolumn{2}{|l}{} \\
\hline Протаномалія (недостатність пігменту L колбочок) & 1.3 & $\mathbf{0 . 0 2}$ \\
\hline Дейтераномалія (недостатність пігменту М колбочок) & 5.0 & 0.35 \\
\hline Дихроматизм & 1.3 & $\mathbf{0 . 0 2}$ \\
\hline Протанопія (відсутність пігменту L колбочок) & 1.2 & 0.01 \\
\hline Дейтеранопія (відсутність пігменту М колбочок) & $\mathbf{0 . 0 0 1}$ & $\mathbf{0 . 0 0 3}$ \\
\hline Тританопія (відсутність пігменту S колбочок) & $\mathbf{0 . 0 0 0 0 1}$ для всіх \\
\hline Монохроматизм (відсутність пігментів всіх типів) &
\end{tabular}

Аномальний трихроматизм - змінення чутливості колбочок до певного кольору.

При пританомалії є дефіцит пігменту L-колбочок. Тобто людина погано розрізняє червоні кольори.

При дейтераномалії є дефіцит М-колбочок. Людина погано розрізняє зелені кольори.

При тританомалії знижена чутливість до синіх кольорів, тобто є дефіцит пігменту S-колбочок.

Дихроматизм - на відміну від аномального трихроматизму, у випадку дихроматизму наявна повна відсутність одного з типу колбочок.

Протанопія - відсутнє сприйняття червоного кольору. Червоні кольори втрачають свою яскравість $\mathrm{i}$ стають сірими. Також червоний колір може замінюватися на темно-зелений або темно-коричневий.

Дейтеранопія - відсутнє сприйняття зеленого кольору. Зелені кольори замінюються світло-оранжевим та світло-коричневим кольорами.

Тританопія - рідкісна форма дихроматизму при якій відсутнє сприйняття синього кольору. Сині кольори замінюються на сірі, а жовті на рожеві.

Не зважаючи на важливість програмних засобів, що допомагають людям 3 порушеннями кольоросприйняття, їх дуже мало, а про адаптовані сайти можна 3 впевненістю говорити про їх недостатню кількість.

"Доступная среда" (http://dostupsreda.ru.) - це інтернет-магазин для людей 3 обмеженими можливостями, що надає товари для полегшення їх інтеграції у суспільство.

Дизайн сайту є слабко пристосованим до потреб дальтоніків, але в функціоналі сайту є модуль, що дозволяє налаштувати зовнішній вигляд сайту відповідно до потреб кожної людини. Головну сторінку сайту наведено на рис. 5. 

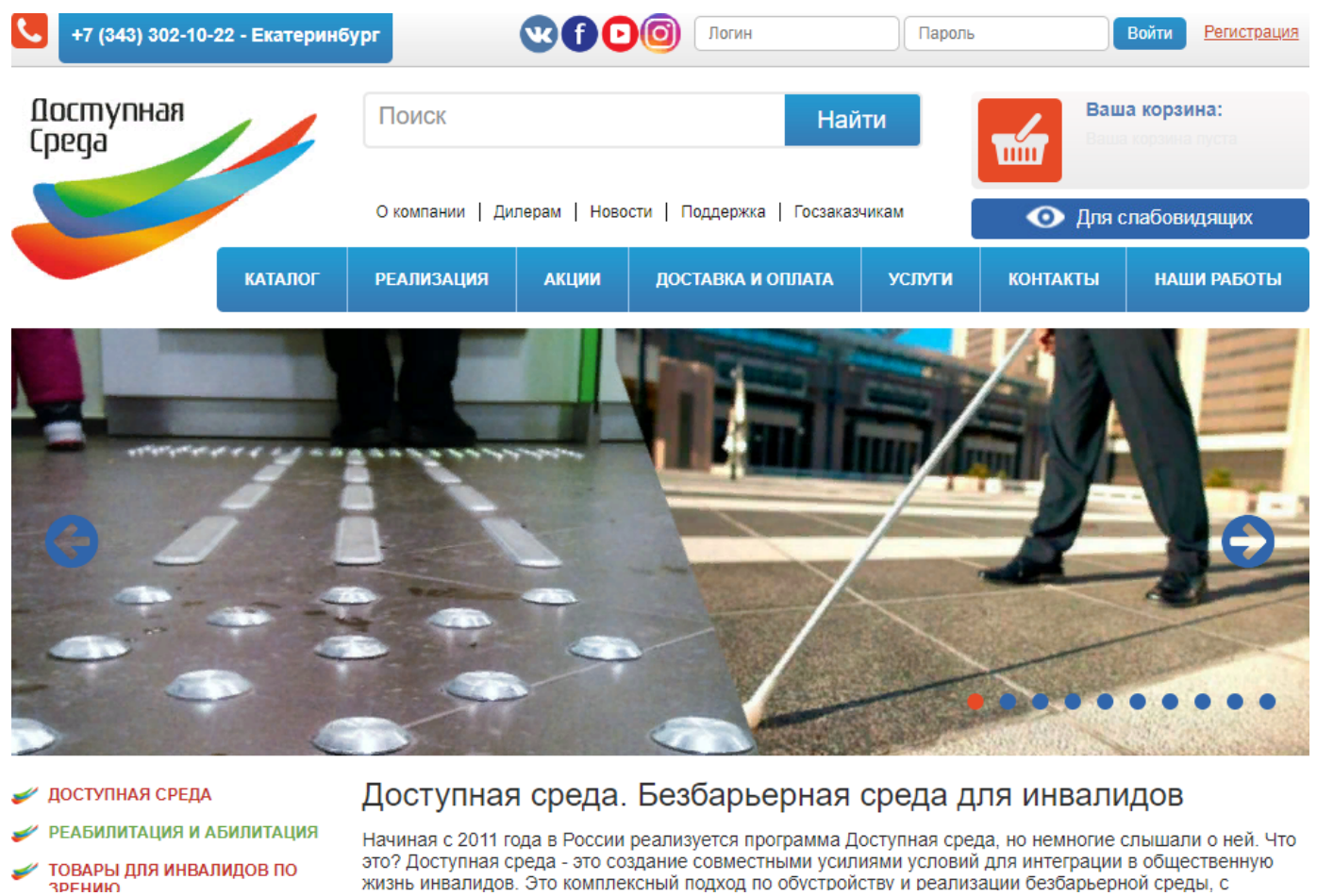

Доступная среда. Безбарьерная среда для инвалидов

Начиная с 2011 года в России реализуется программа Доступная среда, но немногие слышали о ней. Что это? Доступная среда - это создание совместными усилиями условий для интеграции в обещественную

Рис. 5. Головна сторінка сайту "Доступная среда"

Вдалим є рішення дизайну кнопки налаштування версії сайту для людей з порушенням зору та кольоросприйняття. Дану кнопку добре видно навіть за умов порушення зору рис. 6 .

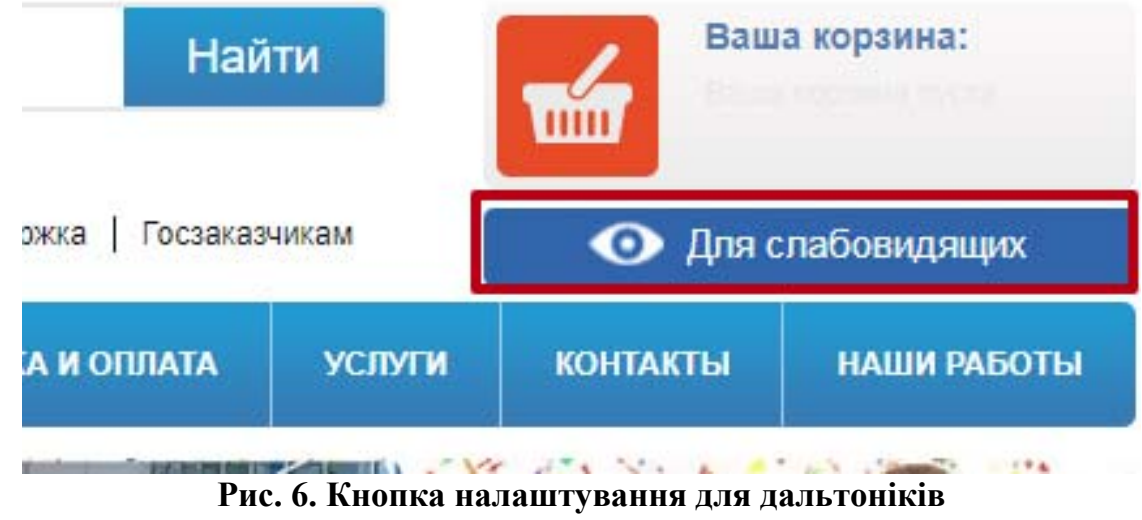

Дизайн даної кнопки дозволить швидко і просто скористатися версією сайту для дальтоніків.

Слід зазначити, що сама версія сайту для слабко зрячих недостатньо відповідає потребам як на рівні реалізації, так і на рівні налаштування - для прикладу можна переглянути вікно налаштувань (рис. 7).

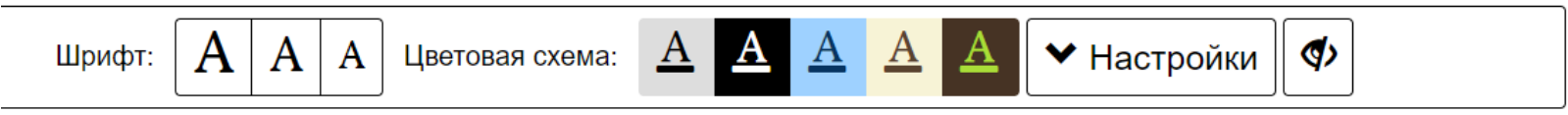

Рис. 7. Меню налаштувань для дальтоніків

Результатом роботи модуля $є$ версія сайту, в якій відсутні зображення, змінено колір посилань та відстань між буквами. При перегляді версій головної сторінки сайту після налаштування (рис. 8), стає зрозуміла низька ефективність такого дизайну. 


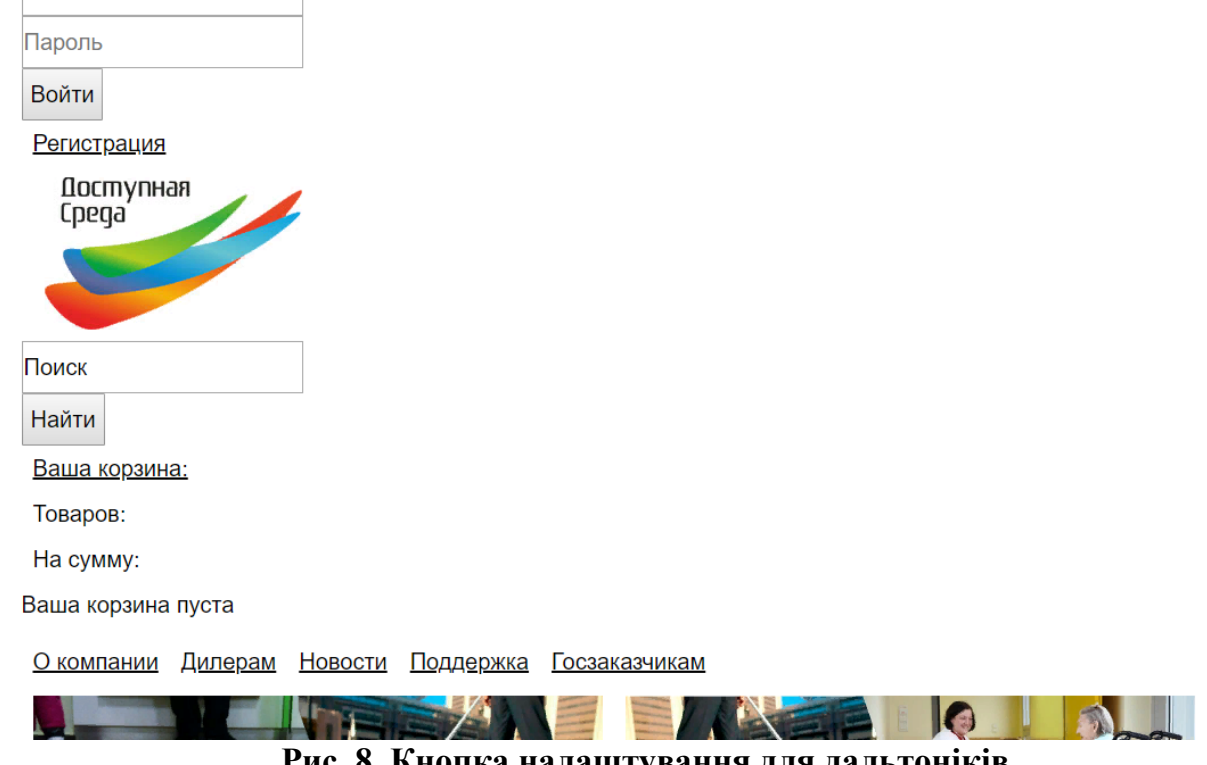

Рис. 8. Кнопка налаштування для дальтоніків

Можна також розглянути сайт Міністерства освіти і науки України. Вдалий дизайн сайту дозволяє швидко знайти кнопку версії сайту для людей із слабким зором. Головну сторінку сайту наведено на рис. 9.

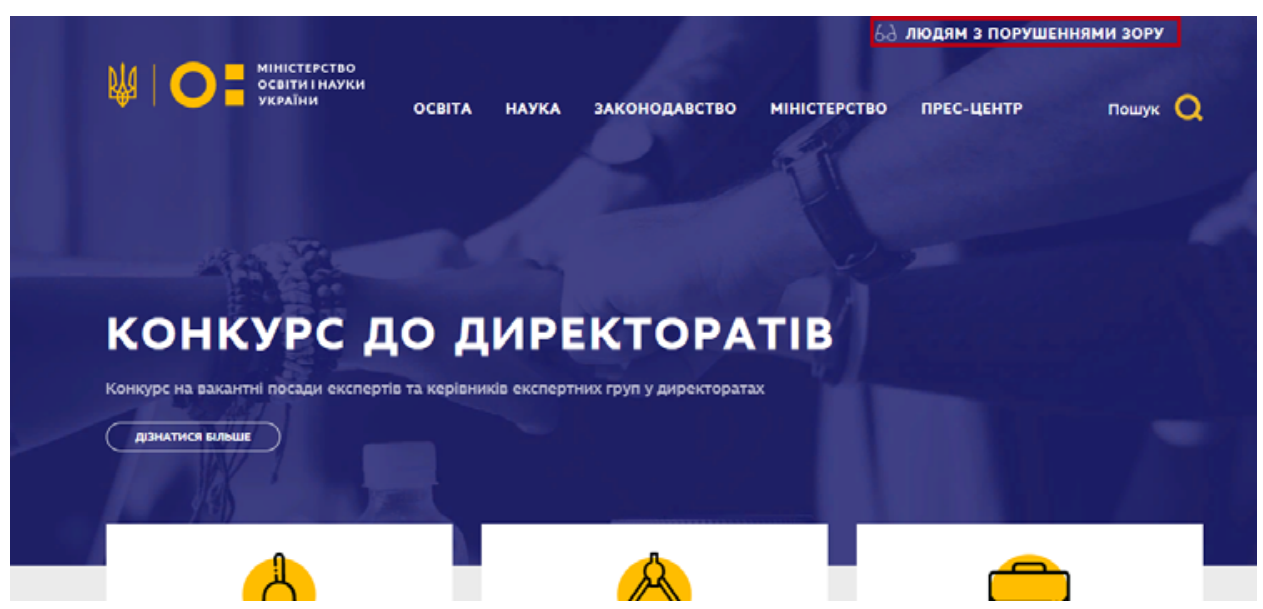

Рис. 9. Головна сторінка сайту Міністерства освіти та науки України

Кнопка виділена червоним прямокутником, активує дизайн для людей із порушеним зором. Приклад сторінки сайту для людей з порушеннями зору на рис. 10.

ЗВИЧАЙНА ВЕРСІЯ

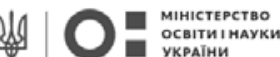

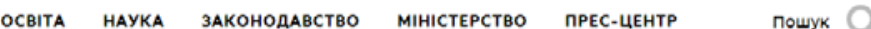

\section{КОНКУРС ДО ДИРЕКТОРАТІВ}

Конкурс на оакантні посапи екепертір та керірникір експертних груп у директоратах
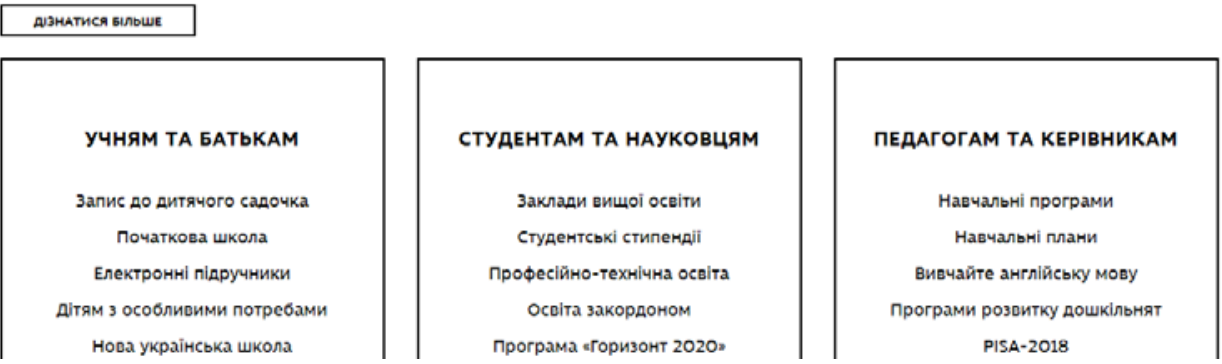

Рис. 10. Головна сторінка сайту Міністерства та освіти України. 


\section{Версія для людей з порушеннями зору}

В такому стані сайт не використовує картинок чи кольорів, окрім чорного та білого, але зберігає положення елементів сайту та спосіб їх виділення при наведені курсору, на активний елемент. I це насправді зручно для людей з порушеним кольоросприйняттям, але не є повноцінним та правильним рішенням.

Також в дизайні передбачена можливість мінімального налаштування. А саме: користувач може, використовуючи кнопки (рис. 11), налаштувати розмір тексту.

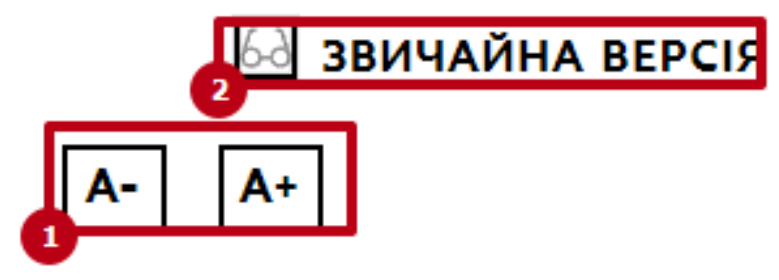

Рис. 11. 1) Кнопки зміни розміру тексту. 2) Кнопка повернення до нормальної версії сайту.

Даний сайт демонструє найпростіше рішення. Але воно не є самим ефективним і зручним для користувачів з порушеннями зору.

Хоча поки що немає версії сайту, розробленої для дальтоніків, версія для людей із частковою сліпотою надає змогу отримувати інформацію на сайті більшій кількості людей.

У даному дослідженні розглянемо такі ПЗ для людей з колірною сліпотою: додаток для браузерів NoCoffee (https://chrome.google.com/webstore/detail/nocoffee/jjeeggmbnhckmgdhmgd ckeigabjfbddl), веб-додаток [9], WhatColor (http://www.hikarun.com/e/), Digital Color Meter (https://support.apple.com/guide/digital-color-meter/welcome/mac), Digital Colorimeter [https:/www.microsoft.com/ru-ru/p/digital-colorimeter/9mwt4twc53mh?activetab=pivot\%3Aoverview $\mathrm{tab}$. Порівняльний аналіз цих ПЗ виконано у табл. 4. Приклади роботи наведено на рис. 12-рис. 14.

Програмні засоби для людей із колірною сліпотою

\begin{tabular}{|c|c|c|}
\hline Назва та тип & Функції & Розробник \\
\hline $\begin{array}{lr}\text { NoCoffee } & - \\
\text { доповнення } \\
\text { браузерів }\end{array}$ & імітація відхилень зору (в тому числі різних типів дальтонізму) & $\begin{array}{l}\text { Аарон Левентал } \\
\text { (приватна } \\
\text { особа) }\end{array}$ \\
\hline $\begin{array}{l}\text { Веб-додаток } \\
\text { А. М. Горло [9] }\end{array}$ & $\begin{array}{l}\text { конвертація колірних стилів сайту таким чином, щоб сайт був } \\
\text { більш зручним для дальтоніків, в залежності від обраного } \\
\text { користувачем типу порушення кольоросприйняття }\end{array}$ & $\begin{array}{l}\text { Анна Горло } \\
\text { (приватна } \\
\text { особа) }\end{array}$ \\
\hline $\begin{array}{l}\text { WhatColor }- \\
\text { програма для } \mathrm{OC} \\
\text { Windows }\end{array}$ & $\begin{array}{l}\text { визначення кольорового значення обраного пікселя на екрані у } \\
\text { системі RGB та назви, яку зрозуміє здорова людина }\end{array}$ & $\begin{array}{l}\text { Хікара Нагата } \\
\text { (приватна } \\
\text { особа) }\end{array}$ \\
\hline $\begin{array}{l}\text { Digital Color Meter } \\
-\quad \text { програма для } \\
\text { ОС Мас }\end{array}$ & $\begin{array}{l}\text { визначення кольорового значення обраного пікселя на екрані у } \\
\text { системі RGB }\end{array}$ & Apple \\
\hline $\begin{array}{l}\text { Digital Colorimeter } \\
-\quad \text { програма для } \\
\text { OC Windows }\end{array}$ & $\begin{array}{l}\text { визначення кольорового значення обраного пікселя на екрані у } \\
\text { системах: RGB, L*a*b, HSV, HLS, CMYK, Yxy }\end{array}$ & Microsoft \\
\hline
\end{tabular}

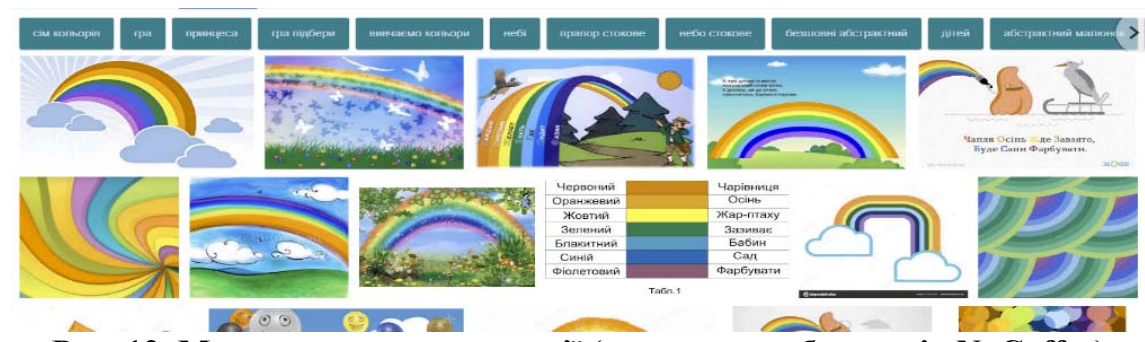

Рис. 12. Моделювання протамалії (додаток для браузерів NoCoffee) 


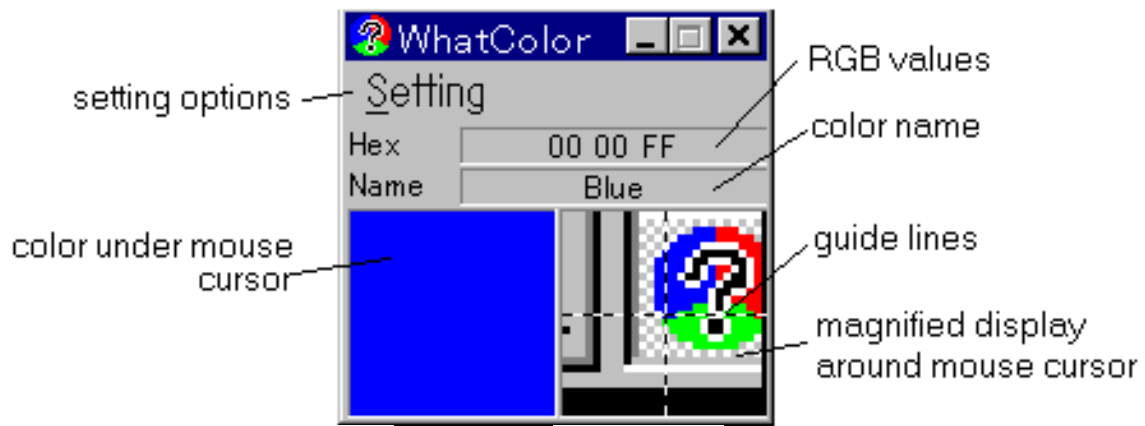

Рис. 13. Інтерфейс програми WhatColor

Серед робіт другого напряму на особливу увагу заслуговує веб-додаток [8]. Для початку роботи необхідно завантажити архів з усіма HTML та CSS файлами сайту (рис. 14).
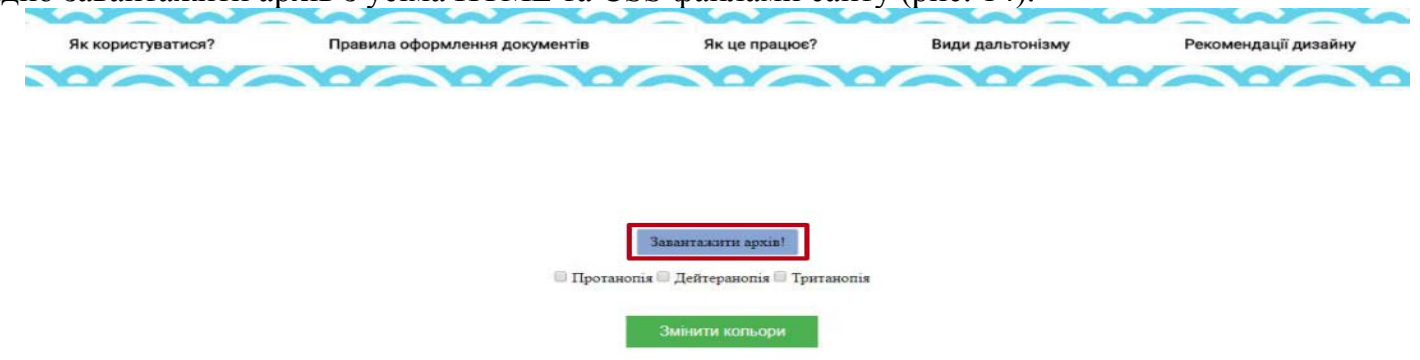

Рис. 14. Інтерфейс веб-додатку, що конвертус кольорові стилі сайту

На даний момент веб-додаток [8] опрацьовує тільки стилі кольору в файлах CSS. Але завдяки можливості зручного налаштування, людина отримує необхідну саме їй версію сайту.

Перспективи подальших досліджень. Слід зазначити, що в даний час відсутня достатня кількість програмних засобів, які б враховували потреби людей з порушеннями зору. Тому кожна нова розробка в даній сфері має значну вагу.

Серед напрямів вдосконалення веб-додатку [8] можна виокремити колірну конвертацію рисунків та колірну конвертацію текстур.

\section{СПИСОК ВИКОРИСТАНИХ ДЖЕРЕЛ ТА ЛІТЕРАТУРИ}

1. Blindness and Vision Impairment [Electronic resource]. - Access mode : http://www.who.int/news-room/factsheets/detail/blindness-and-visual-impairment.

2. Психофизиология : [учебник для вузов] / Под ред. Ю. И. Александрова. - 4-е изд. - СПб. : Питер, 2014. $464 \mathrm{c}$.

3. Schiffman H. R. Sensation and Perception : An Integrated Approach / Harvey Richard Schiffman. - 5th Edition. New York : John Wiley \& Sons, 2001. - 608 p.

4. Kingslake R. Applied Optics and Optical Engieneering / Kingslake Rudolf. - London : Academic Press Inc, 1980. $512 \mathrm{p}$.

5. Петров М. Н. Компьютерная графика : [учебник для вузов. 3-е изд.] / М. Н. Петров. - СПб. : Питер, 2012. $544 \mathrm{c}$.

6. Васильева Э. В. Жизнь в цвете / Эмма Викторовна Васильевна, Оксана Геннадьевна Курмышева. - Омск : Акцент, 2011. - 127 с.

7. Пэдхем Ч. Восприятие цвета и света / Пэдхем Ч., Дж. Сондерс. - М. : Мир, 1978. - 256 с.

8. Горло А. М. Розробка системи адаптації дизайну сайту для людей з порушенням кольоросприйняття : кваліфікаційна робота з напряму підготовки 6.040302 Інформатика / Горло Анна Михайлівна ; Міністерство освіти і науки України, Державний вищий навчальний заклад "Криворізький державний педагогічний університет", фізико-математичний факультет, кафедра інформатики та прикладної математики. - Кривий Ріг, 2018. - 46 с. - Режим доступу : http://elibrary.kdpu.edu.ua/handle/0564/2311.

\section{REFERENCES (TRANSLATED \& TRANSLITERATED)}

1. Blindness and Vision Impairment [Electronic resource]. - Access mode: http://www.who.int/news-room/factsheets/detail/blindness-and-visual-impairment.

2. Psikhofiziologiia [Psychophysiology] : [uchebnik dlia vuzov] / Pod red. Yu. I. Aleksandrova. - 4-e izd. - SPb. : Piter, 2014. - 464 s. (In Russian). 
3. Schiffman H. R. Sensation and Perception : An Integrated Approach / Harvey Richard Schiffman. - 5th Edition. New York : John Wiley \& Sons, 2001.- 608 p.

4. Kingslake R. Applied Optics and Optical Engieneering / Kingslake Rudolf. - London : Academic Press Inc, 1980. $512 \mathrm{p}$.

5. Petrov M. N. Kompiuternaia grafika [Computer Graphics] : [uchebnik dlia vuzov. 3-e izd.] / M. N. Petrov. - SPb. : Piter, 2012. - 544 s. (In Russian).

6. Vasileva E. V. Zhizn' v tsvete [Life in Color] / Emma Viktorovna Vasilevna, Oksana Gennadevna Kurmysheva. Omsk : Aktcent, 2011. - 127 s. (In Russian).

7. Pedkhem Ch. Vospriiatie tsveta i sveta [The Perception of Color and Light] / Pedkhe Ch., Dzh. Sonders. -M. : Mir, 1978. - 256 s. (In Russian).

8. Horlo A. M. Rozrobka systemy adaptatsii dyzainu saitu dlia liudei z porushenniam kolorospryiniattia : kvalifikatsiina robota z napriamu pidhotovky 6.040302 Informatyka [Development of a Website Design Adaptation System for People with Color Blindness] / Horlo Anna Mykhailivna ; Ministerstvo osvity i nauky Ukrainy, Derzhavnyi vyshchyi navchal'nyi zaklad "Kryvorizkyi derzhavnyi pedahohichnyi universytet", fizykomatematychnyi fakul'tet, kafedra informatyky ta prykladnoi matematyky. - Kryvyi Rih, 2018. - 46 s. - Access mode : http://elibrary.kdpu.edu.ua/handle/0564/2311. (In Ukrainian).

\section{Минтий И. С., Вакалюк Т. А., Пирогов В. М., Горло А. М., Минтий М. М. Анализ программных средств для людей с нарушениями зрения.}

Рассмотрены программные средства (ПС) для людей с полной или частичной слепотой (первое направление) и иветовой слепотой (второе направление). Проведён сравнительный анализ по следующим критериям: ПС первого направления - функции, дополнительные возможности, распространение и кампания-разработчик; ПС второго направления - тип, функции, распространение и кампанияразработчик. Приведены примеры работ этих ПС. Особенное внимание уделено веб-приложению конвертации иветовых стилей сайта для людей с нарушениями световосприятия.

Ключевые слова: нарушения зрения, полная слепота, частичная слепота, цветовая слепота, нарушения световосприятия, адаптация дизайна сайта.

\section{Mintii I. S., Vakaliuk T. A., Pirohov V. M., Horlo A. M., Mintii M. M. Analysis of Software for People with Color Blindness.}

One of the priority directions of society progress at the present time is increasing the degree of participation of all citizens in society, first and foremost-citizens with special physical or mental characteristics. Today we can't evaluate the role of computer tools; therefore, special attention in the issue of inclusion should be given for people with visual impairments, including people with color blindness. In this paper, we analyzed software for people with complete or partial blindness and color blindness according to the following scheme: type of software, functions, additional features, developer campaign. So, for people with total or partial blindness the following software is considered: JAWS and NVDA (voice to text on-screen buttons, menus, text documents, etc...), Magnus (zooms in). For people with color blindness, the applications for browsers are considered: NoCoffee (simulates visual impairment), WhatColor, Digital Color Meter, Digital Colorimeter (determine the color value of the selected pixel on the screen in the color system). Among the software, a web application for converting color schemes of the site for people with color blindness is highlighted (to get started, download the archive with all HTML and CSS files of the site). At this time, the application handles only color styles in CSS

files. There are some examples of applications' work in the article. It was concluded that the number and functionality of the software in this direction are insufficient. As a continuation of this study, we highlighted the expansion of the capabilities of a web application for adapting the color design of a site through the implementation of color conversion of images and color conversion of textures.

Key words: visual impairment, complete blindness, partial blindness, color blindness, color disturbances, color scheme conversion, website design adaptation. 